\title{
Histochemical and histomorphometrical studies on the effect of aqueous stem bark extract of Anogeissus leiocarpus on adult wistar rat overies
}

\author{
Murtala M. Jibril ${ }^{*}$, Ojo S. Adeniyi², Bawa E. Kambai ${ }^{3}$ and Zubairu S. Rayyan \\ *Correspondence: mmjibril09@gmail.com

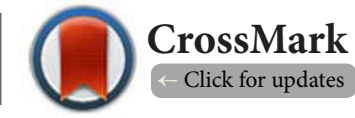 \\ 'Department of Anatomy, Faculty of Medicine Ahmadu Bello University (A.B.U) Zaria, Nigeria. \\ ${ }^{2}$ Department of Veterinary Anatomy, Faculty of Veterinary Medicine, Ahmadu Bello University (A.B.U) Zaria, Nigeria. \\ ${ }^{3}$ Department of Theriogenology, Faculty of Veterinary Medicine, Ahmadu Bello University (A.B.U) Zaria, Nigeria.
}

\begin{abstract}
The effect of aqueous stem bark extract of Anogeissus leiocarpus on the histochemical and histomorphologic changes in the rat ovaries using PAS and Hematoxylin and eosin for light microscopy was studied in twentyfour $(\mathrm{n}=24)$ young adult wistar strain rat. Four experimental groups were assigned and received an extract concentration of $600 \mathrm{mg} / \mathrm{kg}, 400 \mathrm{mg} / \mathrm{kg}$, and $200 \mathrm{mg} / \mathrm{kg}$ as groups IV, III and II, while the control group (I) received distilled water, for the period of six (6) weeks. The histological slides of the ovaries showed no gross or histological changes as a result of the extract administration. The granulosa cells in the ovarian cortex indicate a PAS-positive reaction, thus confirming the accumulation of glycogen in the tissue as a result of the extract administration. The microscopic sections of the ovaries indicated that the extract does have an effect on folliculogenesis in a dose dependent pattern. There was a significant decrease in the number of primary and tertiary follicles observed in the high dose group IV $(600 \mathrm{mg} / \mathrm{kg})$, and a significant increase in the number of primary follicle in group II $(400 \mathrm{mg} / \mathrm{kg})$, compared with the control group $(\mathrm{p}<0.05)$. The study concluded that the stem bark extract of Anogeissus leiocarpus extract does have an effect on follicular dynamics.
\end{abstract}

Keywords: Anogeissus leiocarpus, ovaries, histochemistry, histomorphometry

\section{Introduction}

Anogeissus leiocarpus (DC) Guill. \& Perr. is a common plant distributed across the African savanna region, mostly across the West and Central Africa [3]. It has many local names in different languages across Africa. It is referred to as "Orin-odan" in Yoruba, and "Marke" in Hausa. A. leiocarpus is still locally used for problems associated with reproduction in many parts of Northern Nigeria.

The effect of $A$. leiocarpus extract on reproduction and fertility has not been investigated. Many of the plant materials used in traditional medicine are readily available in rural areas and this has made traditional medicine relatively cheaper than modern medicine [4]. Over Sixty percent of Nigeria rural populations depend on traditional medicine for their healthcare need [4].

Phytochemical studies conducted on A. leiocarpus revealed that the stem bark extracts has various chemical constitutions such as alkaloids, glycosides, steroid, anthraquinone, phenol, tannins, saponins, calcium and fluorides [1].

\section{Materials and methods Experimental animals}

Twenty-four young adult Wistar rats weighing between 135-150g per group were obtained from the department of pharmacology of Ahmadu Bello University Zaria, Kaduna state, Nigeria. They were kept in plastic cages and maintained under laboratory condition at room temperature and humidity. Water and standard pellet diet were provided to the rats ad libitum. All animals received care in compliance with the guidelines of the ethical committee of medical research, ABU Zaria. There after, the animals were divided into four groups of six animals each.

\section{Plant material}

The fresh stem bark of $A$. leiocarpus, readily available within the Ahmadu Bello University Zaria, were collected and authenticated in the herbarium of Biological Sciences Department of ABU Zaria by a taxonomist U.S. Gallah with a voucher specimen number 1738 for future reference. Two kilogram of A. leiocarpus stem 
bark was air dried, minced and powdered using a clean, sterile laboratory mortar. $50 \mathrm{~g}$ of the resulting powder was dissolved in 0.5 liters of distilled water using a soxhlet extractor. The solution was allowed to settle for twenty-four hours and filtered with Whartmann's filter paper. The resultant solute was allowed to settle for one hour, and placed in water bath under reduced pressure at $35^{\circ} \mathrm{C}$ for evaporation. The extract was weighed and dissolved in distilled water to prepare the stock solution.

\section{Experimental procedure}

Twenty-four ( $n=24)$ adult female wistar rats were used for the study. The animals were randomly assigned into four groups I, II, III and IV, each group consisting of six animals selected at random. Each group was placed in a separate cage. The experimental groups were given rat pellets and various concentrations of aqueous extract of $A$. leiocarpus of varying concentrations of the extract gavage, corresponding to $600 \mathrm{mg} / \mathrm{kg}\left(1 / 2 \mathrm{LD}_{50}\right)$ for group $\mathrm{Vl}, 400 \mathrm{mg} / \mathrm{kg}\left(1 / 3 \mathrm{LD}_{50}\right)$ for group III, and $200 \mathrm{mg} / \mathrm{kg}\left(1 / 4 \mathrm{LD}_{50}\right)$ for group II, the control group I, were given food and distilled water for the period of six weeks.

\section{Histological studies}

The reproductive organs; Ovaries, uterus and the uterine horns, were harvested immediately after the rats were sacrificed. They were weighed in analytical balance, and fixed in $10 \%$ Bouin's fixative solution. Tissue sections were prepared and stained using Hematoxylin \& Eosin stain for light microscopy. Photomicrographs were obtained using a microscope eyepiece attached to a computer.

\section{Histometrical studies}

Histometrical study was conducted using the method of [2]. Paraffin sections of $3 \mu \mathrm{m}$ thickness were cut on a microtome and stained with Hematoxylin and eosin (H\&E) for morphometry and enumeration of ovarian follicles. Homologous cross sections of the entire ovary showing a better area of vision were chosen. The ovarian section was traced around the tissue boundaries with the computerized software and a sampling grid was superimposed over the section. Each square of the sampling grid represent a sampled area measuring $6400 \mu \mathrm{m}$. A counting frame was then used to sample a pre-determined area within each square of the sampling grid. Section area was calculated by integrating the area inside the traced perimeter and volume calculated by multiplying the section thickness.

\section{Statistical analysis}

The results obtained were analyzed using Statistics 5.0 software and Microsoft Excel 2007. All results were expressed a mean value $\pm S E M$. The variance of the data and the confidence interval were determined using the analysis of variance (ANOVA) and a value of $\mathrm{P}<0.05$ was considered as statistically significant. Dunnet's post hoc tests were used to determine where the level of significance lies.

\section{Results}

Effect of anogeissus leiocarpus extract on body weight of the animals

The effects of the extract on body weight showed a slight increase in weight of the animals across the experimental groups (Table 1). It is more visible in experimental groups II and III compared to the control. However, the mean weight taken at the end of the experiment showed that the increase in weight is not statistically significant $(P \leq 0.05)$.

Effect of different doses of extract on the weight of the reproductive tract of the animals

The reproductive tract (fallopian tubes, ovaries, and the uterus) of the experimental rats, showed no significant difference in weight $(P \leq 0.05)$ at the end of the extract administration in groups II and III when compared with the control group (Table 2). There is a statistically significant increase however in the high dose group (IV) $(P \leq 0.05)$ compared to the control.

\section{Effect of different doses of extract on the number of ovarian follicles}

There was an increased folliculogenesis, which shows an increase in the number of tertiary follicles in the treatment group that received $200 \mathrm{mg} / \mathrm{kg}$ (group II) compared with the control (Table 3). An increase in primary and secondary follicles was also observed in the group that received extract concentration of $400 \mathrm{mg} / \mathrm{kg}$ (group III) was also observed $(P \leq 0.05)$ compared to the control group.

\section{Histological slides}

The histological features of the ovaries in the experimental group (II) showed normal features of the ovary as evidence by the presence of follicles in different stages of development, as in the control group (Figure 1). There is normal histological architecture of the ovary with the cortex and the medulla clearly visible, and the presence of oocytes at different stages of development. There was an increase in the number of secondary follicles in the treatment group that received extract concentration of $400 \mathrm{mg} / \mathrm{kg}$ (group III), a distinct follicles can be seen in the ovarian surface (Figure 2), with the outer surface epithelium, and the tunica albuginea, as seen in the control group.

The presence of more primary follicle (PF) was observed in the group that received extract concentration of $200 \mathrm{mg} /$ $\mathrm{kg}$ (group II), as compared with the control. The presence of outer surface epithelium (OSE) and the tunica albuginea can also be seen (Figure 3 ).

\section{Discussion}

Changes in body weight were observed across all the experimental groups. This increase was more pronounced in the treatment groups (I, II and III). The increase in the weight of the control group was non-significant. This suggests that the extract did have an effect on the rate of food intake and 
Jibril et al. Journal of Histology \& Histopathology 2015,

http://www.hoajonline.com/journals/pdf/2055-091X-2-20.pdf

Table 1. Effect of extract administration of Anogeissus leiocarpus on body weight of rats after 6 week.

\begin{tabular}{|c|c|c|c|c|c|c|c|c|c|}
\hline \multirow[t]{2}{*}{ Group } & \multirow[t]{2}{*}{$\mathbf{n}$} & $\begin{array}{l}\text { Mean weight } \\
\text { (g) } \pm \text { SEM }\end{array}$ & $\begin{array}{l}\text { Mean weight } \\
\text { (g) } \pm \text { SEM }\end{array}$ & $\begin{array}{l}\text { Mean weight }(g) \\
\pm \text { SEM }\end{array}$ & $\begin{array}{l}\text { Mean weight } \\
\text { (g) } \pm \text { SEM }\end{array}$ & $\begin{array}{l}\text { Mean weight }(\mathrm{g}) \\
\pm \text { SEM }\end{array}$ & $\begin{array}{l}\text { Mean weight }(\mathrm{g}) \\
\pm \text { SEM }\end{array}$ & $\begin{array}{l}\text { Mean weight }(\mathrm{g}) \\
\pm \text { SEM }\end{array}$ & P-value \\
\hline & & 0week & $1^{\text {st }}$ & $2^{\text {nd }}$ & $3^{\text {rd }}$ & $4^{\text {th }}$ & $5^{\text {th }}$ & $6^{\text {th }}$ & \\
\hline I-Control & 6 & $146 \pm 5.1$ & $145 \pm 5.0$ & $146 \pm 5.1$ & $146 \pm 5.1$ & $147 \pm 5.3$ & $146 \pm 5.1$ & $147 \pm 4.0$ & 0.47 \\
\hline II-200mg/kg & 6 & $142 \pm 4.2$ & $142 \pm 4.2$ & $143 \pm 4.3$ & $145 \pm 4.8$ & $144 \pm 4.5$ & $146 \pm 4.7$ & $146 \pm 4.9$ & 0.46 \\
\hline III- $400 \mathrm{mg} / \mathrm{kg}$ & 6 & $137 \pm 4.1$ & $137 \pm 4.1$ & $138 \pm 4.2$ & $139 \pm 4.3$ & $140 \pm 5.3$ & $141 \pm 3.9$ & $141 \pm 5.1$ & 0.46 \\
\hline IV-600mg/kg & 6 & $135 \pm 4.5$ & $134 \pm 4.7$ & $135 \pm 4.5$ & $137 \pm 4.1$ & $137 \pm 3.9$ & $138 \pm 4.0$ & $141 \pm 5.3$ & 0.49 \\
\hline
\end{tabular}

$\mathrm{P}>0.05 ; \mathrm{SEM}=$ Standard Error in Mean; $\left({ }^{*}\right)=$ Stastical Significance

Table 2. Weight of the Uterus, fallopian tubes, and Ovaries across the experimental groups.

\begin{tabular}{llll}
\hline Group & $\begin{array}{l}\text { Weight of Uterus, } \\
\text { fallopian tubes, } \\
\text { and Ovaries Mean } \\
\text { weight }(\mathrm{g}) \pm \text { SEM }\end{array}$ & $\begin{array}{l}\text { Body weight/ } \\
\text { Organ ratio } \\
\text { Mean weight } \\
(\mathbf{g}) \pm \text { SEM }\end{array}$ & P-value \\
\hline I-Control & $0.54 \pm 0.04$ & $242 \pm 5.3$ & 0.043 \\
II-200mg/kg & $0.56 \pm 0.04$ & $260 \pm 5.1$ & 0.047 \\
III-400mg/kg & $0.56 \pm 0.04$ & $251 \pm 4.9$ & 0.046 \\
IV-600mg/kg & $0.57 \pm 0.06$ & $272 \pm 4.0$ & $0.057^{\star}$ \\
\hline
\end{tabular}

$\mathrm{P}<0.05 ; \mathrm{SEM}=$ Standard Error in Mean; ${ }^{*}=$ Statistically significant

Table 3. Number of follicles across each experimental group.

\begin{tabular}{llll}
\hline Group & \multicolumn{3}{c}{ Follicles } \\
\hline & $\begin{array}{l}\text { Primary follicles } \\
\text { Mean } \pm \text { SEM }\end{array}$ & $\begin{array}{l}\text { Secondary follicles } \\
\text { Mean } \pm \text { SEM }\end{array}$ & $\begin{array}{l}\text { Tertiary follicles } \\
\text { Mean } \pm \text { SEM }\end{array}$ \\
\hline I-Control & $96.3 \pm 3.70^{*}$ & $39.8 \pm 2.90$ & $13.6 \pm 1.47$ \\
II-200mg/kg & $94.2 \pm 3.70$ & $37.1 \pm 2.90$ & $14.2 \pm 1.47^{*}$ \\
III-400mg/kg & $98.7 \pm 3.70$ & $47.1 \pm 2.90^{*}$ & $12.5 \pm 1.47$ \\
IV-600mg $/ \mathrm{kg}$ & $87.1 \pm 3.70$ & $34.1 \pm 2.90$ & $2.8 \pm 1.47$
\end{tabular}

$\mathrm{P}<0.05 ; \mathrm{SEM}=$ Standard error in mean; ${ }^{*}=$ Statistically Significant

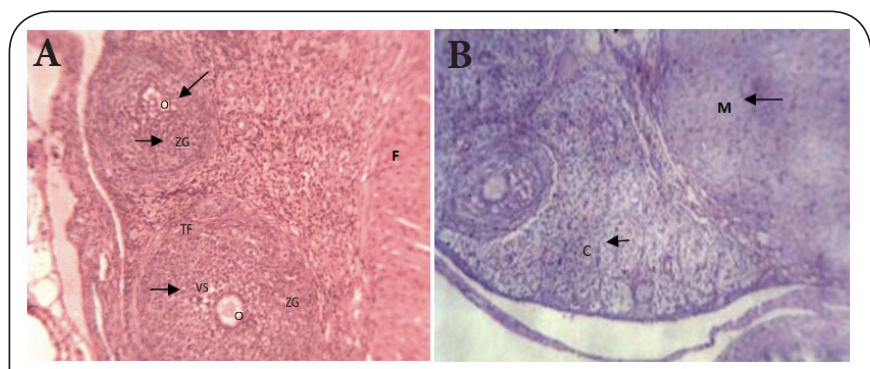

Figure 1. Photomicrograph showing a cross section of the ovary of (A) Group that received 200mg/kg body weight, (B) Control group, showing normal architecture of the ovary with primary Oocyte (O); Theca Folliculi (TF); Vesicular Spaces (VS); Zona Granulosa (ZG); Ovarian Cortex (C); Ovarian Medulla (M). (H\&Ex100).

utilization, thus confirming the studies conducted by [6], on the hypoglycemic effect of the leaf extract of $A$. leiocarpus on blood glucose utilization in wistar rats, which has more effect at a dose of $400 \mathrm{mg} / \mathrm{kg}$.

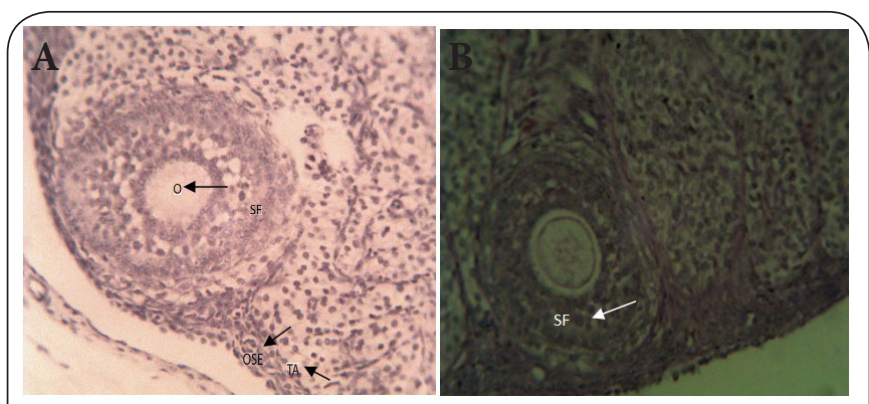

Figure 2. Photomicrograph showing a cross section of the ovary of (A) Group III received $400 \mathrm{mg} / \mathrm{kg}$ body weight, and (B) Control group, both showing normal architecture of the ovary with primary Oocyte (O); Outer Surface Epithelium (OSE); TunicaAlbuginea (TA). (Pasx250).

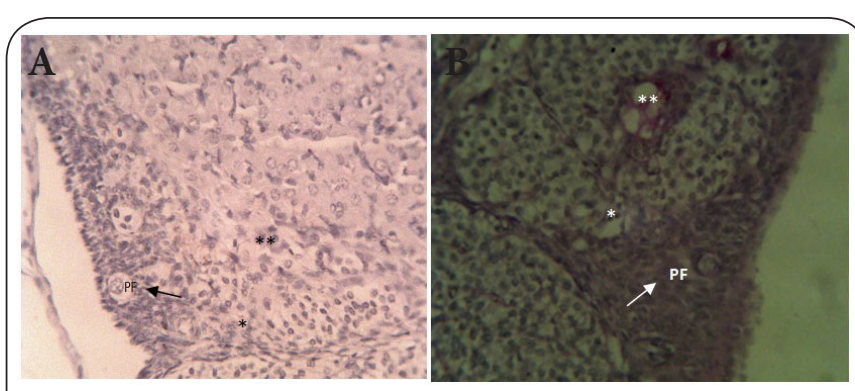

Figure 3. Photomicrograph showing the cross section of the ovary with a primary follicle from (A) Group II that received $200 \mathrm{mg} / \mathrm{kg}$, and (B) Control group; $\left(^{*}\right)$ positive PAS reaction. (PASx250).

The histological slides of the ovaries showed no gross or histological changes as a result of the extract administration. There was simple cuboidal epithelium with typical features throughout its extent. The medulla was well formed and contains blood vessels and abundant amount of fibroconnective tissue. The medulla was well formed and shows normal histological structure of the wistar rat ovary.

A precise border between the cortex and the medulla cannot be distinguished, characteristics of the normal structure of the mouse ovary. There was a significant decrease in the number of primary and tertiary follicles $(2.8 \pm 1.47 ; 87.1 \pm 3.70)$, compared with the control group $(96.8 \pm 3.70)$. Also, a significant increase in the number of primary follicle in group II 
$(400 \mathrm{mg} / \mathrm{kg})$, compared with the control group was observed, $(98.7 \pm 3.70)$, and $(96.8 \pm 3.70)$. This finding is the first reported on the effect of the stem bark extract of Anogeissus leiocarpus on follicular dynamics.

\section{Competing interests}

The authors declare that they have no competing interests.

\section{Authors' contributions}

\begin{tabular}{|l|c|c|c|c|}
\hline Authors' contributions & MMJ & OSA & BEK & ZSR \\
\hline Research concept and design & $\checkmark$ & $\checkmark$ & -- & -- \\
\hline Collection and/or assembly of data & $\checkmark$ & $\checkmark$ & $\checkmark$ & $\checkmark$ \\
\hline Data analysis and interpretation & $\checkmark$ & $\checkmark$ & $\checkmark$ & -- \\
\hline Writing the article & $\checkmark$ & -- & -- & -- \\
\hline Critical revision of the article & $\checkmark$ & $\checkmark$ & $\checkmark$ & $\checkmark$ \\
\hline Final approval of article & $\checkmark$ & $\checkmark$ & $\checkmark$ & $\checkmark$ \\
\hline Statistical analysis & $\checkmark$ & -- & $\checkmark$ & -- \\
\hline
\end{tabular}

\section{Acknowledgement}

We wish to acknowledge the contribution of Umar Ahmad of the Universiti Putra Malaysia (UPM) for his contribution to data analysis, and Mr. Mairiga of the department of histopathology ABUTH Shika, Zaria for helping during my slide preparation.

\section{Publication history}

EIC: Gaetano Giuseppe Magro, University of Catania, Italia. Received: 23-Jul-2015 Final Revised: 25-Aug-2015

Accepted: 01-Sep-2015 Published: 10-Sep-2015

\section{References}

1. Mann A, Y. Yahaya, A. Banso and G. O. Ajayi. Phytochemical andantibacterialscreening of Anogeissus leiocarpus against some microorganisms associated withinfectious wounds. Academic Journals. 2010.

2. Plowchalk D.R, B.J. Smith and D.R. Mattison. Methods in toxicology. Academic Press Inc. 1993; 57-66.

3. Takahashi T and Ohnishi J. Molecular mechanism of follicle rupture during ovulation. Zoolog Sci. 1995; 12:359-65. | Article | PubMed

4. Apulu N, Dada J. O, Odama L. E. and Galadima M. Antibacterial activity of aqueousextract of some Nigerian medicinal plants. Nigerian Journal of Botany. 1994; 7:45-48.

5. Smith BJ, Plowchalk DR, Sipes IG and Mattison DR. Comparison of random and serial sections in assessment of ovarian toxicity. Reprod Toxicol. 1991; 5:379-83. | Article | PubMed

6. Chen TH, Chen SC, Chan P, Chu YL, Yang HY and Cheng JT. Mechanism of the hypoglycemic effect of stevioside, a glycoside of Stevia rebaudiana. Planta Med. 2005; 71:108-13. | Article | PubMed

\section{Citation:}

Jibril MM, Adeniyi OS, Kambai BE and Rayyan ZS.

Histochemical and histomorphometrical studies on the effect of aqueous stem bark extract of Anogeissus leiocarpus on adult wistar rat overies. J Histol

Histopathol. 2015; 2:20.

http://dx.doi.org/10.7243/2055-091X-2-20 